\title{
Flexural Behavior of Sisal/Castor Oil-based Polyurethane and Sisal/Phenolic Composites
}

\author{
Andressa Cecília Milanese*, Maria Odila Hilário Cioffi, Herman Jacobus Cornelis Voorwald
}

\author{
Faculdade de Engenharia de Guaratinguetá - FEG, \\ Departamento de Materiais e Tecnologia, Grupo de Fadiga e Materiais Aeronáuticos, \\ Universidade Estadual Paulista - UNESP, São Paulo, SP, Brazil
}

Received: March 17, 2011; Revised: December 1, 2011

\begin{abstract}
Natural fibers used as reinforcement of polymeric composites are interesting research subjects in polymer technology. Nowadays, these materials are being considered as a way to reinforce timber structures improvement. Fibers with larger structural applications are glass and carbon fibers, however, the use of natural fibers is an economic alternative and present many advantages such as biodegradability and having its origin from a renewable source. Castor oil, a triglyceride vegetable with hydroxyl groups, was reacted with 4,4' methylene diphenyl diisocyanate (MDI) to produce the polyurethane matrix. The composites were prepared by compress molding at room temperature using woven sisal fiber as a reinforcement, with and without thermal treatment (at $60{ }^{\circ} \mathrm{C}$ for 72 hours) to the fabrics before the composites molding process. The present paper presents the preparation and a flexural caracterization of sisal/polyurethane and sisal/phenolic composites by using the three-point bending. The sisal fibers moisture content influence on the flexural behaviour was also analyzed. Experimental results showed a higher stiffness for the sisal/phenolic composite (11.2 MPa) followed by the sisal/polyurethane (3.7 MPa), respectively.
\end{abstract}

Keywords: flexural behavior, castor oil-based polyurethane, sisal fiber, polymeric composite

\section{Introduction}

Natural fibers, classified as lignocellulosic materials, have been used as reinforcement materials once they present innumerable advantages, such as low specific mass, low superficial damage in the equipment, easy handling, biodegradability, having its origin from a renewable source, being a thermal, electric and acoustic insulator, having aesthetic aspects, non-toxicity, and besides having a low $\operatorname{cost}^{1-4}$. In the automobile industry, they have a great potential to be applied in the internal covering area of cars, buses and trucks. It also contributes to the civil construction field to reinforce cement, used as a textile material, characterizing a market in expansion ${ }^{4}$.

The raw material from renewed resources is of great interest due to the possible replacement of fibers originated from petrochemical derivatives, which may contribute to the environment.

Brazil has a great production of sisal and it is exported to the entire world, with a production of 111.600 tons, in 2005. It is also responsible for $58 \%$ of the worldwide production $^{5}$. The main producing states in Brazil are Bahia - $93.5 \%$, Paraíba - 3.5\% and Rio Grande do Norte - 3\%, the semiarid region ${ }^{6}$.

Sisal fibers are extracted from Agave sisalana perrine leaves. The microstructure of the natural fibers is constituted from cellulose fiber, reinforcing the amorphous hemicelluloses and lignin matrices. Natural fibers have moisture content, in general, ranging between 5 to $20 \%$, due to the hydrophilic characteristic of the cellulosic fiber. This characteristic

*e-mail: andressa.cm@ig.com.br affects the mechanical properties of the composites because the moisture can lead to a poor processability and porous products during the processing of composites ${ }^{7-10}$. According to $\mathrm{Li}$, Mai and $\mathrm{Ye}^{9}$, to modify the fiber surface structure in order to enhance the bond strength between the fiber and the matrix and to reduce the water absorption of sisal fiber, chemical and thermal treatments are used.

A thermal treatment or hydrothermal treatment at temperatures about $120{ }^{\circ} \mathrm{C}$ is not appropriate for natural fibers, since it increases fiber brittleness and reduces strength. So, a thermal treatment process at a temperature that is higher than $120^{\circ} \mathrm{C}$ reduces moisture absorption with deterioration of other fiber properties ${ }^{11}$.

There are many reports about sisal fiber composites, Paiva and Frollini ${ }^{12}$ studied unmodified and modified surface sisal fibers by mercerization (alkali treatment) using $\mathrm{NaOH}$ $10 \%$, esterification (succinic anhydride) and ionized air treatment on phenolic and lignophenolic matrices. The study showed an improvement on the fiber/matrix interfacial adhesion by mercerization and esterification when compared to the ionized air treatment. Mwaikambo and Ansell ${ }^{13,14}$ and Rong et al. ${ }^{15}$ also observed that the fiber surface topography and the crystallographic index changes with mercerization treatment. However, they observed that depending on the $\mathrm{NaOH}$ concentration, there is a reduction of fiber thermal resistance.

Bismarck et al. ${ }^{16}$ reported that the sisal fibers thermal stability is not affected by the dewaxing treatment while the mercerization and methyl methacrylate grafting increases 
the maximum decomposition temperature by $10{ }^{\circ} \mathrm{C}$ compared to untreated fibers. Jacob et al. ${ }^{17}$ investigated the influence of mercerization $(\mathrm{NaOH} 4 \%)$, silane and thermal $\left(150{ }^{\circ} \mathrm{C}\right.$ for 8 hours) treatments on the tensile strength in woven sisal fabric reinforcing natural rubber composites. The study shows that the highest values are exhibited by thermally treated composites besides providing a better adhesion and a stronger interface than any other chemical modifications.

Castor oil is a vegetable triglyceride, which is not employed for feeding. The molecule is characteristically formed by hydroxyl groups and applied as a polyol in the synthesis of cross-linked polyurethane ${ }^{18}$. Figure 1 shows the representative composition of the oil. Viscous liquid castor oil is obtained from expressing or extracting with a solvent from Ricinus communis plant seeds, which belong to the Eurphorbiacae family ${ }^{19,20}$.

Castor plant grows in countries with tropical and subtropical climates that present average temperatures at about $20-26^{\circ} \mathrm{C}$ and low air humidity. The main producers are India, China and Brazil, which were responsible for $92 \%$ of the worldwide production in $2001^{[21]}$. The yearly worldwide production of seeds is about 1 million tons, consequently, the oil production remains at around 500,000 tons $^{20,22}$. There is a different variety of castor seeds, but in average, it is possible to obtain 46 to $55 \mathrm{wt}$. (\%) of oil ${ }^{20}$. This oil is a natural resource, which is considered to be closer to a pure compound, where $87-90 \%$ of the fatty acid presented in their constitution is the ricinoleic acid. About 10-13\% are non-hydroxylated fatty acids, which include linoleic and oleic acids ${ }^{18,23}$. The use of this oil on the synthesis of polyurethane produces a polymer which is less aggressive to humans and to the environment ${ }^{24}$.

Silva ${ }^{3}$ studied the behavior of plates from castor oilbased polyurethane resin with coconut and sisal as plain weaves, unidirectional short fibers (10 mm of length) and unidirectional long fibers. Results show that sisal fibers present the best results when compared to coconut fibers. The raises of fibers content fraction increase tensile strength, stiffness and water absorption, but it decreases the flexural strength. Polymeric laminates of epoxy and castor oil-based polyurethane resins reinforced with unidirectional sisal fibers were studied by Carvalho ${ }^{25}$ to reinforce timber structures. It was observed that the use of these composites is technically viable for the application as reinforcement. Mercerization treatment $(\mathrm{NaOH} 10 \%)$ on the sisal woven fabric for an hour reduces the composites variability on tensile behavior, although it decreases stiffness and tensile strength.
Fiorelli ${ }^{24}$ analyzed the utilization of polymeric composites composed by epoxy, polyurethane or phenolic resin reinforced with glass or carbon unidirectional textiles when used to reinforce lower pieces of timber structures. He concluded that the increase of stiffness and flexural strength is proportional to the number of textile layer and the use of one carbon layer is equivalent to three glass fiber layers.

The study of sisal fiber and castor oil-based polyurethane as raw material in the production of composites contributes to environmental preservation once these materials are derived from natural, biodegradable and renewable resources. The objective of this paper is to present the preparation and the mechanical characterization by flexural behavior of sisal composites which are manufactured with castor oil-based polyurethane and phenolic matrices by compressing molding. The main purpose of the sisal composites development is to be used as reinforcement of civil structures. The application of a thermal treatment in the sisal fibers is to promote the fiber surface modification by improving fiber/matrix adhesion and, consequently, the flexural properties.

\section{Experimental}

\subsection{Fibers}

Woven sisal fabric, received in the form of plain weave ${ }^{26}$ (bi-directional), was used as reinforcement and obtained from Northeast Brazil, shown in Figure 2. The fabric presents $2.4 \mathrm{~mm}$ of thickness and Table 1 presents sisal physics characteristics.

Fibers in natural condition used as received was denominated as "untreated", while the fibers thermally treated in the oven at $60{ }^{\circ} \mathrm{C}$ for 72 hours was denominated "thermally treated". Determination of moisture regain $(h)$ in the sisal fibers was calculated according to the ASTM D1348 standard ${ }^{27}$, method A, using the Equation 1:

$h(\%)=\frac{M-D}{D} \times 100$

where $h$ is the moisture regain, in percentage; $M$ is the original mass of specimen and $D$ is the mass of oven-dry specimen at $105^{\circ} \mathrm{C}$.

\subsection{Resins}

The castor oil-based polyurethane and the phenolic resins were used as matrices.

The castor oil-based polyurethane is cured at room temperature. Kehl Industry Ltda from Brazil provides these<smiles>[R]C(=O)OCC(COC([R])=O)OC([R])=O</smiles>

where:

$$
\begin{aligned}
& \mathrm{R}_{1}=-\left(\mathrm{CH}_{2}\right)_{7} \mathrm{CH}=\mathrm{CH}-\mathrm{CH}_{2}-\stackrel{\mathrm{OH}}{\mathrm{CH}}\left(-\mathrm{CH}_{2}\right)_{5}-\mathrm{CH}_{3} \\
& \mathrm{R}_{2}=\text { other fatty acid derivates }
\end{aligned}
$$

Figure 1. Castor oil triglyceride. 
reagents and has its patent. Resin is a bi-component formed by a polyol and a pre-polymer commercially designated as D405 and IC201, respectively and only the polyol components may be evaluated as bio-based materials ${ }^{28}$.

The polyol D405 is liquid at room temperature, presenting a yellow color and having its density in the range of $1.0-1.2 \mathrm{~g} . \mathrm{cm}^{-3}$ according to the manufacturer. It is soluble in water and produces biodegradable residue ${ }^{29}$. The pre-polymer IC201 is composed by 4,4'- methylene diphenyl diisocyanate (MDI), whose structure is displayed in Figure 3. It is liquid at room temperature, with a dark brown color and its density at $1.24 \mathrm{~g} . \mathrm{cm}^{-3}$, as informed by the manufacturer. This reagent is insoluble in water; however, it reacts producing $\mathrm{CO}$ and it is an inert and not biodegradable residue ${ }^{29}$.

Cascophen RS 216 M is a water-based synthetic phenolic resin with room temperature curing, and manufactured by

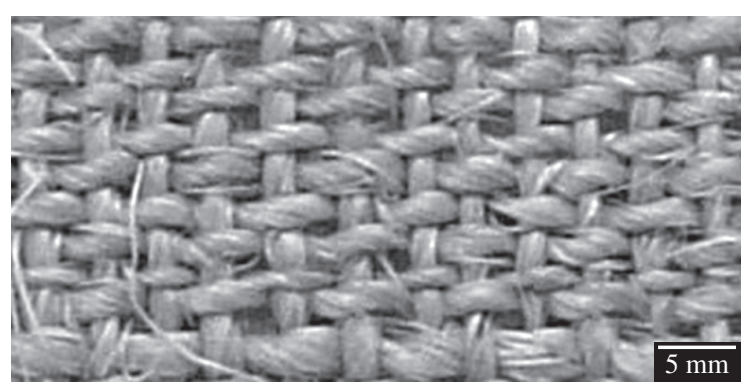

Figure 2. Plain weave sisal fabric.

Table 1. Physics properties of woven sisal fabric.

\begin{tabular}{cc}
\hline Average Yarn distance (weft), in $\mathrm{mm}$ & 2.00 \\
Average Yarn distance (warp), in $\mathrm{mm}$ & 3.50 \\
Diameter of fiber*, in $\mu \mathrm{m}$ & $100-200$ \\
\hline
\end{tabular}

*data by SEM.<smiles>O=[N+]([O-])c1ccc(Cc2ccc([N+](=O)[O-])cc2)cc1</smiles>

Figure 3. 4,4' Methylene diphenyl diisocyanate.
Alba Adhesives Ind. Com. Ltda. It is formed from a liquid resin and its hardener (formaldehyde), which is presented in the form of beige powder. After mixing the two components, it results in a waterproof polymer which is resistant to fungi ${ }^{30}$, presenting a dynamic viscosity of 0.53-0.65 Pa.s, and gel time at around 3.5-6.0 hours at $21^{\circ} \mathrm{C}^{[31]}$.

Reagents were mixed according to the stoichiometric quantity of 2:1 in mass of polyol and isocyanate, respectively, and 5:1 in mass of phenolic and catalyzer, respectively. The components were manually mixed for about five minutes, followed by a deposition in a silicon mold with $3.3 \mathrm{~mm}$ of thickness.

\subsection{Composites}

Sisal/polyurethane composites with 44 wt. (\%) of reinforcement and sisal/phenolic composites with $33 \mathrm{wt}$. (\%) of reinforcement were prepared by compress molding at room temperature. The resin components were manually mixed and shed upon fibers. Laminate thickness is the equivalent of a fabric layer and samples were removed from the mold after 4-8 days processed. The fibers were arranged between glass flat plates pressed after the bubble extraction with a metal roller. Plastic sheets were used as a releasing agent for polyurethane laminates.

\subsection{Flexural test}

Flexural tests of resins and composites were performed using a universal machine, INSTRON, model 4301 and samples were carried out at room temperature. Three-point bending tests were performed according to the ASTM D790 standard $^{32}$, at a load-cell of $500 \mathrm{Kgf}$ and a minimum of six specimens per test condition were tested.

Phenolic resin used a crosshead speed of $1.5 \mathrm{~mm} / \mathrm{min}$, while the PU resin and composites used a crosshead speed of $2.0 \mathrm{~mm} / \mathrm{min}$. The ratio used between the supports distance and the thickness of samples in the test was 16. Flexural stresses tested are calculated following Equation 2:

$\sigma_{f}=\frac{3 \cdot P \cdot L}{2 \cdot b \cdot d^{2}}$

where $\sigma_{f}$ is the stress in the outer fibers at midpoint (MPa), $P$ is the load (N), $L$ is the support span $(\mathrm{mm}), b$ is the width of beam tested (mm), and $d$ is the depth of beam ( $\mathrm{mm})$.

Table 2. Flexural data of resins and composites.

\begin{tabular}{|c|c|c|c|c|c|c|}
\hline \multirow[b]{2}{*}{ Properties } & \multicolumn{2}{|c|}{ Resins } & \multicolumn{4}{|c|}{ Composites } \\
\hline & $\mathbf{P U}$ & Phenolic & $\begin{array}{c}\text { Untreated } \\
\text { sisal/PU } \\
h=17.1 \%\end{array}$ & $\begin{array}{c}\text { Thermally } \\
\text { treated sisal/PU } \\
h=6.0 \%\end{array}$ & $\begin{array}{c}\text { Untreated } \\
\text { sisal/phenolic } \\
h=17.1 \%\end{array}$ & $\begin{array}{c}\text { Thermally } \\
\text { treated sisal/ } \\
\text { phenolic } \\
h=6.0 \%\end{array}$ \\
\hline Flexural strength (MPa) & 0.45 & 8.6 & 1.6 & 3.7 & 10.7 & 11.2 \\
\hline Standard deviation & 0.05 & 2.4 & 0.16 & 0.34 & 1.1 & 0.7 \\
\hline Coefficient of variation (\%) & 11.1 & 28.2 & 10.3 & 9.26 & 10.2 & 6.06 \\
\hline Deflection (mm) & 18.4 & 3.0 & 17.2 & 16.8 & 14.0 & $\mathbf{1 7 . 5}$ \\
\hline Standard deviation & 0.51 & 0.74 & 0.78 & 0.46 & 0.3 & 0.5 \\
\hline Coefficient of variation (\%) & 2.78 & 24.4 & 4.54 & 2.71 & 2.38 & 3.02 \\
\hline
\end{tabular}

PU - Castor oil-based polyurethane 
Samples fracture surface resulted in the phenolic resin flexural tests were analyzed by scanning electron microscopy (SEM), Jeol make, JSM5310 model. The surface analyzed was cut from the fractured samples and covered by a thin gold layer.

\section{Results and Discussion}

Table 2 shows flexural data of all tested materials: castor oilbased polyurethane (PU) resin, phenolic resin, untreated sisal/ PU composite, thermally treated sisal/PU composite, untreated sisal/phenolic and thermally treated sisal/phenolic composite.

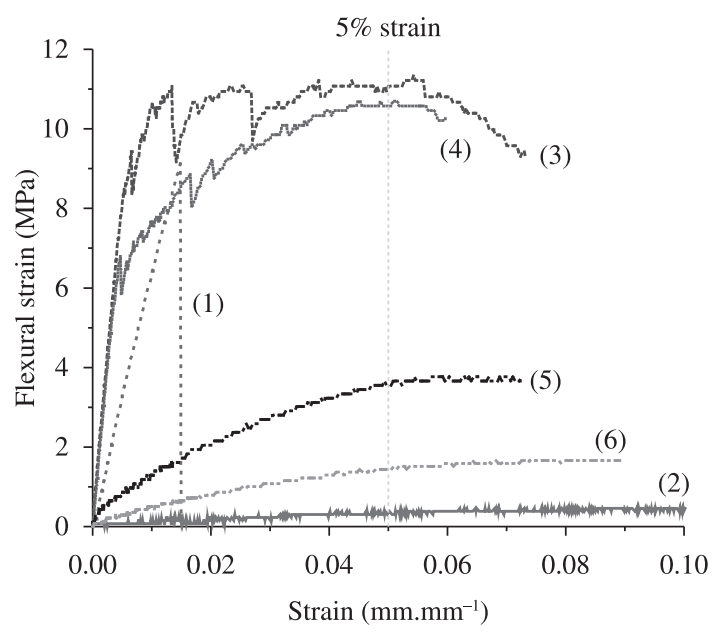

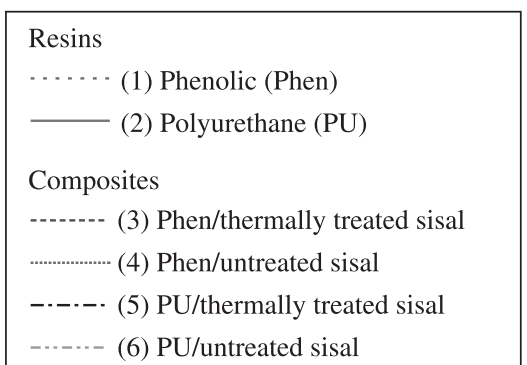

Figure 4. Flexural curves of resins and composites: A sample for each condition tested.
Flexural strength of polyurethane resin is $0.45 \mathrm{MPa}$ with a deflection of $18.4 \mathrm{~mm}$, thus this resin shows low flexural strength and high extension without break, which can be considered as a ductile material, opposite to the behavior presented in the phenolic resin.

The polyurethane resin and all composites do not break/ fail at strains of up to $5 \%$, so the maximum flexural stress were calculated according to Equation 2, using for the load value $(P)$, the amount corresponding to $5 \%$ of strain. The Figure 4 shows flexural curves of a sample for each material tested, and the different behaviors between resins and composites could be observed.

Flexural stress of the phenolic resin is $8.6 \mathrm{MPa}$ and its deflection at break is $3.0 \mathrm{~mm}$. It was observed that specimens give a load deflection curve, which demonstrates a break point without a yield point. This resin is a fragile material, considering that the phenolic resin shows low extension before breaking. Taking into account that the flexural strength values show a high variation coefficient, the results show a considerable low precision. According to the experimental flexural tests (Figure 4), only the phenolic resin specimens presented failure (break) at strains of up to $5 \%$, and the fractographic study was possible by using SEM. Fractures start from the tensioned border towards the center of the sample, which can be observed in Figures 5 and 6 .

Flexural strength of untreated sisal/phenolic composites in comparison to thermally treated sisal/phenolic composites does not show a significant difference between both presented values, which is around 11.0 MPa. However, the reduction in the standard deviation and the increase on the deflection were differences with the reduction of moisture content of fiber, so the use of thermally treated sisal is favorable to produce sisal/phenolic composites to be used as reinforcement of civil structures. Regarding the fiber moisture content, it is evident that the absence of moisture collaborates to adhesion of the matrix/fiber and, as a consequence, thermal treatment of sisal fiber is recommended when used with the phenolic matrix. Sisal/ phenolic composite, with an addition of one layer, introduces an increase of about $28 \%$ on the flexural strength when compared to the phenolic matrix.

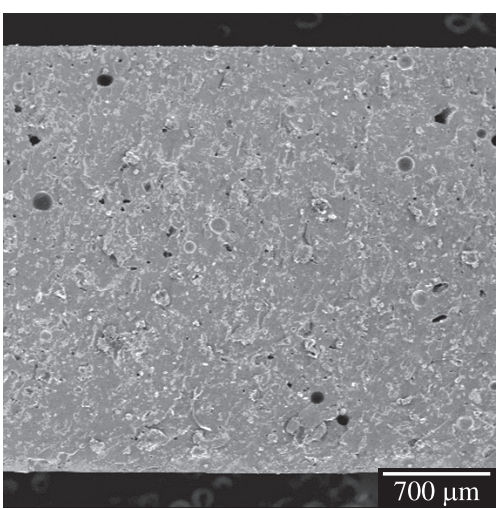

(a)

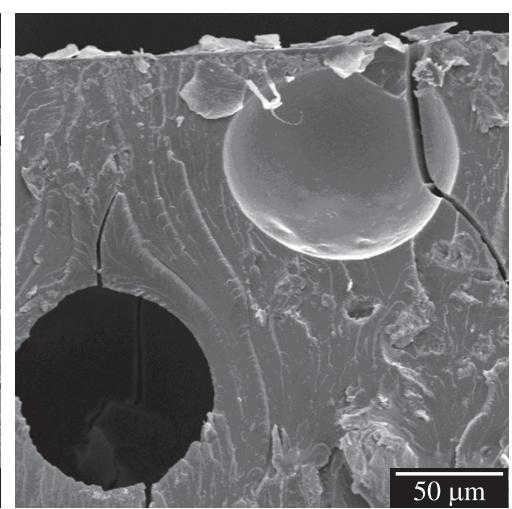

(b)

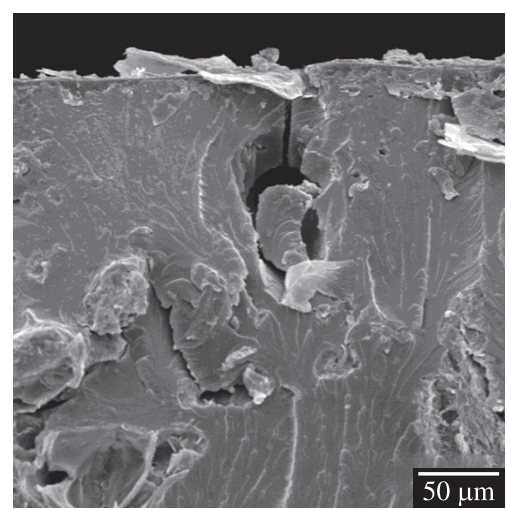

(c)

Figure 5. Phenolic resin specimen fracture after flexural test: a) macrograph (35x); b) presence of voids (500x) and c) presence of impurities $(750 \times)$. 


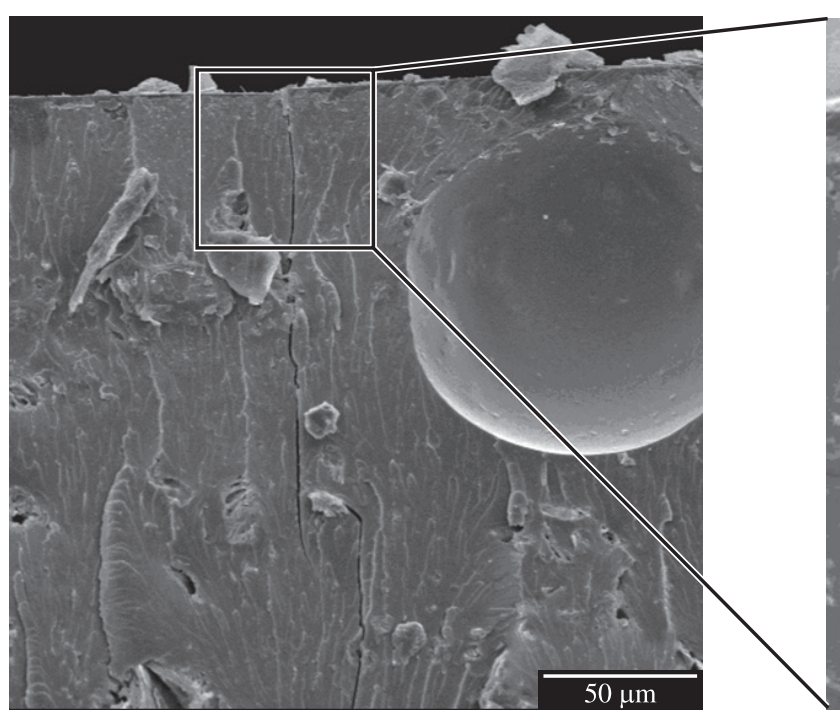

(a)

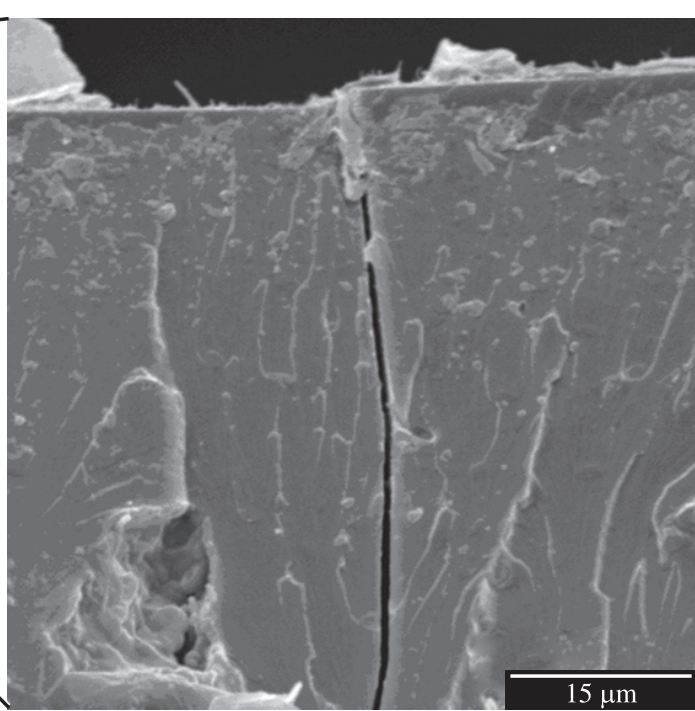

(b)

Figure 6. Phenolic resin fractograph: a) fracture from tensioned border to the center of sample $(500 \times)$ and b) fracture starts from tensioned border $(2000 \times)$.

Thermally treated sisal/PU composite presents a flexural strength of about twice the value when compared to the untreated sisal/PU composite. The presence of moisture in the fibers could serve as an expansion agent in the polyurethane polymerization, once the reaction between water and isocyanate results on the carbon dioxide $(\mathrm{CO})$ that is responsible to form bubbles in the matrix and, consequently, decrease the contact area fiber/matrix and the strength ${ }^{33}$.

Regarding the deflection of untreated and thermally treated fiber composites, a significant difference between values was not found. Differences were found between the composites with fiber moisture reduction, such as increasing the standard deviation of flexural strength, unfavorable factors for the use of this material in civil structures. However, there were reductions in the variation coefficient of the flexural strength and displacement. Based on the experimental results, the absence of moisture content in the sisal provide a higher flexural strength to the polyurethane composite in a way that the heat treatment is indicated to sisal fibers when this composite is used to reinforce timber structures.

With an addition of one layer, untreated sisal/PU composite has an equivalent flexural strength at 3.5 times when compared to the PU matrix, while thermally treated sisal/PU composite corresponds to 8.2 times.

Considering that flexural strength of PU and phenolic matrices were used as reference for the analysis of results, flexure strength values of composites were higher than the ones presented in the respective matrix, in a way that, the addition of reinforcement promoted an increase in them, different from the ones presented by Silva ${ }^{3}$.

As shown in Table 2, sisal/phenolic composites (11.0 MPa) with untreated or thermally treated sisal fabric presents a higher flexural strength followed by thermally treated sisal/PU (3.7 MPa) and untreated sisal/PU composites (1.6 MPa), respectively.
Table 3. Static bending of woods ${ }^{34}$.

\begin{tabular}{lcc}
\hline \multicolumn{1}{c}{$\begin{array}{c}\text { Common and botanical } \\
\text { names of species }\end{array}$} & Flexural strength (MPa) \\
\cline { 2 - 3 } & Green wood & $\begin{array}{c}\text { 12\% moisture } \\
\text { content }\end{array}$ \\
\hline $\begin{array}{l}\text { Andiroba } \\
\text { (Carapa guianensis) }\end{array}$ & 71.0 & 106.9 \\
$\begin{array}{l}\text { Angelin } \\
\text { (Andira inermis) }\end{array}$ & - & 124.1 \\
$\begin{array}{l}\text { Parana-pine } \\
\text { (Araucaria augustifolia) }\end{array}$ & 49.6 & 93.1 \\
$\begin{array}{l}\text { Peroba rosa } \\
\text { (Aspidosperma } \text { spp.) }\end{array}$ & 75.2 & 83.4 \\
$\begin{array}{l}\text { Pine, Caribbean } \\
\text { (Pinus caribaea) }\end{array}$ & 77.2 & 115.2 \\
$\begin{array}{l}\text { Primavera } \\
\text { (Tabebuia donnell-smithii) }\end{array}$ & 49.6 & 65.5 \\
$\begin{array}{l}\text { Santa Maria } \\
\text { (Calophyllum brasiliense) }\end{array}$ & 72.4 & 100.7 \\
$\begin{array}{l}\text { Spanish-cedar } \\
\text { (Cedrela } \text { spp.) }\end{array}$ & 51.7 & 79.3 \\
\hline
\end{tabular}

Experimental results indicate that the use of phenolic composites to reinforce timber structures is viable, once these composites present a considerable strength to the application based on the flexural strength (static bending) presented of some woods and that are reported in Table 3.

\section{Conclusions}

Thermal treatment of sisal fabric reinforcement applied before molding the polyurethane composite was suitable when considering its flexural behavior, once the treatment increases notable flexural strength. 
Considering the flexural behavior of the sisal/ phenolic composite, the thermal treatment of sisal reinforcement is indicated for the production of structural phenolic composites because the treatment decreases the scattering of the flexural strength data and increases the deflection.

The best performance in flexural mode to reinforce structures, when considering the flexural strength and its deflection, was the thermally treated sisal/phenolic followed by untreated sisal/phenolic, thermally treated sisal/PU and untreated sisal/PU composites, respectively.

\section{References}

1. Saheb DN and Jog JP. Natural Fiber Polymer Composites: A Review. Advances in Polymer Technology. 1999; 18(4): 351-363. http://dx.doi.org/10.1002/(SICI)1098-2329(199924)18:4\%3C3 51::AID-ADV6\%3E3.0.CO;2-X

2. Carvalho RF and Calil Junior C. Sisal Fiber Woven Tension Strength. In: Anais do VIII Encontro Brasileiro de Madeiras e em Estruturas de Madeira; 2002; Uberlândia. Uberlândia: Univ Federal de Uberlândia; 2002. CD-ROM.

3. Silva RV. Composite based on polyurethane resin derived from castor oil and vegetable fibers. [Tese]. São Carlos: University of São Paulo; 2003. Available from: <http://www.teses.usp. br/>. Access in: 11/03/2005.

4. Mothé $\mathrm{C}$ and Araújo CR. Thermal and mechanical characterization of polyurethane composites with curauá fibers. Polímeros. 2004; 14(4):274-278.

5. Andrade W. Sisal of Brazil. 2009. Available from: <http:// www.braziliansisal.com/?page_id=17\&lang=pt $>$. Access in: 08/07/2010.

6. Brazilian Trade and Investment Promotion Agency - APEX Brasil. Sisal lives new boom. 2006. Available from: <http:// www.apexbrasil.com.br/noticia_detalhe.aspx?idnot=265>. Access in: 31/10/2006.

7. Jacob M, Varughese KT and Thomas S. A study on the moisture sorption characteristics in woven sisal fabric reinforced natural rubber biocomposites. Journal of Applied Polymer Science. 2006; 102(1):416-423. http://dx.doi.org/10.1002/ app. 24061

8. Mattoso LHC, Ferreira FC and Curvelo AAS. Sisal Fiber: Morphology and Applications in Polymer Composites. In: Proceedings of International Symposium on LignocellulosicsPlastics Composites; 1997; São Paulo. São Paulo: USP/ UNESP; 1997. p. 241-266.

9. Li Y, Mai Y and Ye L. Sisal fibre and its composites: a review of recent developments. Composites Science and Technology. 2000; 60(11):2037-2055. http://dx.doi. org/10.1016/S0266-3538(00)00101-9

10. Mishra S, Mohanty AK, Drzai LT, Misra M and Hinrichsen G. A review on pineapple leaf fibers, sisal fibers and their biocomposites. Macromolecular Materials and Engineering. 2004; 289(11):955-974. http://dx.doi. org/10.1002/mame.200400132

11. Frollini E, Paiva JMF, Trindade WG, Razera IAJ and Tita SP. Plastics and Composites from Lignophenols. In: Wallenberger FT and Weston N, editors. Natural Fibers, Plastics and Composites. The Netherlands: Kluwer Academic Publishers Group; 2004. p. 193-225. http://dx.doi.org/10.1007/978-14419-9050-1_12
Experimental results indicate that the use of phenolic composites to reinforce timber structures is viable, once these composites present considerable strength for the application according to their practical use.

\section{Acknowledgements}

The authors express their acknowledgements for the financial support provided by $\mathrm{CNPq}$ through processes $\mathrm{n}^{\circ} 310215 / 2006-4$ and $\mathrm{n}^{\circ} 134015 / 2005-3$ and FUNDUNESP through process $\mathrm{n}^{\circ} 00576 / 06$.

12. Paiva JMF and Frollini E. Unmodified and Modified Surface Sisal Fibers as Reinforcement of Phenolic and Lignophenolic Matrices Composites: Thermal Analyses of Fibers and Composites. Macromolecular Materials and Engineering, 2006; 291(4):405-417. http://dx.doi.org/10.1002/ mame. 200500334

13. Mwaikambo LY and Ansell MP. The effect of chemical treatment on the properties of hemp, sisal, jute and kapok for composite reinforcement. Die Angewandte Makromolekulare Chemie. 1999; 272(1):108-116. http://dx.doi.org/10.1002/ (SICI)1522-9505(19991201)272:1\%3C108::AID-APMC108\% 3E3.0.CO;2-9

14. Mwaikambo LY and Ansell MP. Chemical modification of hemp, sisal, jute, and kapok fibers by alkalization. Journal of Applied Polymer Science. 2002; 84(12):2222-2234. http:// dx.doi.org/10.1002/app.10460

15. Rong MZ, Zhang MQ, Liu Y, Yang GC and Zeng HM. The effect of fiber treatment on the mechanical properties of unidirectional sisal-reinforced epoxy composites. Composites Science and Technology. 2001; 61(10):1437-1447. http:// dx.doi.org/10.1016/S0266-3538(01)00046-X

16. Bismarck A, Mohanty AK, Aranberri-Askargorta I, Czapla S, Misra M, Hinrichsenb G et al. Surface characterization of natural fibers; surface properties and the water up-take behavior of modified sisal and coir fibers. Green Chemistry. 2001; 3:100-107. http://dx.doi.org/10.1039/b100365h

17. Jacob M, Varughese KT and Thomas S. Novel Woven Sisal Fabric Reinforced Natural Rubber Composites: Tensile and Swelling Characteristics. Journal of Composites Materials. 2006; 40(16):1471-1485. http://dx.doi. org/10.1177/0021998306059731

18. Trân NB, Vialle J and Phan QT. Castor oil-based polyurethanes: 1. Structural characterization of castor oil nature of intact glycerides and distribution of hydroxyl groups. Polymer. 1997; 28(10):2467-2473.

19. Vilar WD. Chemistry and Technology of Polyurethanes. 2006. Available from: <http://www.poliuretanos.com.br>. Access in: 03/03/2006.

20. Ogunniyi DS. Castor oil: A vital industrial raw material. Bioresourse Technology. 2006; 97(9):1086-1091. http://dx.doi. org/10.1016/j.biortech.2005.03.028

21. Biodiesel. World Production from Castor Beans. Available from: <http://www.biodieselbr.com/plantas/mamona/ producao-mundial-mamona.htm>. Access in: 14/03/2006.

22. Santos RF and Barros MAL. Cultivation of castor bean. Embrapa; 2000. Available from: <http://sistemasdeproducao. cnptia.embrapa.br/FontesHTML/Mamona/CultivodaMamona/ importancia.htm>. Access in: 10/05/2006. 
23. Silvestre Filho GD. Mechanical behavior of carbon fiber reinforced polyurethane derived from castor oil: contribution for the design of hip implant stems. [Dissertacão]. São Carlos: University of São Paulo; 2001. Available from: <http://www. teses.usp.br/>. Access in: 10/03/2005.

24. Fiorelli J. Exploitation of carbon fiber and glass fiber to reinforcements of timber beams. [Dissertacão]. São Carlos: University of São Paulo; 2002. Available from: <http://www. teses.usp.br/>. Access in: 11/03/2005.

25. Carvalho RF. Sisal composites to reinforcement of timber structures. [Tese]. São Carlos: University of São Paulo; 2005. Available from: <http://www.teses.usp.br/>. Access in: $11 / 03 / 2006$.

26. ASM International. Engineered Materials Handbook: Composites. 4th ed. ASM; 1993.

27. American Society for Testing and Materials - ASTM. ASTM D 1348: Standard Test Methods for Moisture in Cellulose. ASTM; 2003.

28. Ajjithkumar S, Kansara SS and Patel NK. Kinetics of castor oil based polyol-toluene diisocyanate reactions. European Polymer
Journal. 1998; 34(9):1273-1276. http://dx.doi.org/10.1016/ S0014-3057(97)00270-X

29. KEHL. 2006. Available from: <http://www.kehl.ind.br/>. Access in: 10/03/2006.

30. Alba adhesives. 2006. Available from: <http://www. albaadesivos.com.br>. Access in: 06/03/2006.

31. Alba adhesives. FISPq-Information Index Safety Chemical: Cascophen RS 216 M. 2004.

32. American Society for Testing and Materials - ASTM. ASTM $D$ 790: Standard Test Method for Flexural Properties of Unreinforced and Reinforced Plastics and Electrical Insulating Materials. ASTM; 2003.

33. Cangemi JM, Santos AM and Claro Neto S. Polyurethane: from pillow to preservative, a versatile polymer. Química Nova na Escola. 2009; 31(03):159-164. Available from: <http:// qnesc.sbq.org.br/online/qnesc31_3/02-QS-3608.pdf>. Access in: 01/08/2011.

34. Green DW, Winandy JE and Kretschmann DE. Mechanical Properties of Wood. Wood handbook-Wood as an engineering material. Forest Products Laboratory; 1999. Chapt. 4, 463 p. 